\title{
EFEKTIVITAS PENERIMAAN DAN KONTRIBUSI RETRIBUSI DAERAH TERHADAP PENDAPATAN ASLI DAERAH KABUPATEN MERANGIN
}

\author{
Desy Karmila \\ Prodi Keuangan Daerah FEB Universtias Jambi \\ desykarmila@gmail.com
}

\begin{abstract}
Abstrak
Penelitian ini bertujuan untuk mengetahui dan menganalisis kontribusi retribusi daerah (PAD) dan jenis retribusi daerah terhadap Pendapatan Asli Daerah Kabupaten Merangin Tahun 2009-2013 dan mengetahui dan menganalisis efektivitas retribusi daerah Kabupaten Merangin Tahun 2009-2013. Alat analisis yang digunakan dalam penelitian ini adalah dengan analisis kontribusi dan analisis efektivitas. Hasil penelitian ini menunjukkan bahwa kontribusi retribusi daerah terhadap Pendapatan Asli Daerah di Kabupaten Merangin selama tahun 2009- 2013 adalah sedang berkontribusi dengan rata-rata sebesar 25,08 persen. Kontribusi retribusi daerah jenis jasa umum terhadap Pendapatan Asli Daerah Kabupaten Merangin selama tahun 2009-2013 adalah kurang berkontribusi dengan rata-rata sebesar 19,24 persen. Kontribusi retribusi daerah jenis jasa usaha rata-rata sebesar 4,20 persen dan masih sangat kurang berkontribusi, kemudian kontribusi retribusi daerah perizinan tertentu selama tahun 2009-2013 adalah sangat kurang berkontribusi dengan rata-rata sebesar 1,67 persen, sedangkan tingkat efektivitas retribusi daerah Kabupaten Merangin selama tahun 2009-2013 rata-rata sebesar 87,03 persen (cukup efektif).
\end{abstract}

Kata Kunci : Penerimaan, Retribusi Daerah, Kontribusi PAD.

\begin{abstract}
This study aims to determine and analyze the contribution of regional user fees (PAD) and types of local user fees to the Merangin Regency Original Revenue in 2009-2013 and to know and analyze the effectiveness of the regional levies of Merangin District in 2009-2013. The analytical tool used in this study is the contribution analysis and effectiveness analysis. The results of this study indicate that the contribution of regional levies to the Original Revenue in Merangin Regency during 2009-2013 is being contributed by an average of 25.08 percent. The contribution of regional service types levies to the Merangin Regency's Original Revenue during 2009-2013 was less contributing with an average of 19.24 percent. The contribution of regional levies in the types of business services is an average of 4.20 percent and is still very undercontributing, then the contribution of certain regional licensing levies during 2009. 2013 is very less contributing with an average of 1.67 percent, while the level of effectiveness of regional levies Merangin Regency in 2009-2013 averaged 87.03 percent (quite effective).
\end{abstract}

Keywords: Revenue, Regional Retribution, PAD Contribution

\section{PENDAHULUAN}

Pendapatan Asli Era Otonomi Daerah yang secara resmi mulai diberlakukan di Indonesia sejak 1 januari 2001 menghendaki daerah untuk berkreasi dalam mencari sumber penerimaan yang dapat membiayai pengeluaran pemerintah daerah dalam 
rangka menyelenggarakan pemerintahan dan pembangunan. Dari berbagai alternatif penerimaan daerah, Undang-undang tentang Pemerintahan Daerah dan juga UndangUndang tentang Perimbangan Keuangan antara Pemerintah Pusat dan Daerah menetapkan pajak dan retribusi daerah sebagai sumber Daerah (PAD) yang bersumber dari dalam daerah itu sendiri (Marihot Pahala Siahaan, 2013).

Berdasarkan Undang-Undang Nomor 23 Tahun 2014 Otonomi daerah adalah hak, wewenang, dan kewajiban daerah otonom untuk mengatur dan mengurus sendiri urusan pemerintahan dan kepentingan masyarakat setempat sesuai dengan peraturan perundang-undangan. Sedangkan Daerah otonom, selanjutnya disebut daerah, adalah kesatuan masyarakat hukum yang mempunyai batas-batas wilayah yang berwenang mengatur dan mengurus urusan pemerintahan dan kepentingan masyarakat setempat menurut prakarsa sendiri berdasarkan aspirasi masyarakat dalam sistem Negara Kesatuan Republik Indonesia ( UU No 23 tahun 2014).

Untuk meningkatkan pelaksanaan pembangunan dan pemberian pelayanan kepada masyarakat serta peningkatan, pertumbuhan perekonomian di daerah diperlukan penyediaan sumber-sumber pendapatan asli daerah yang hasilnya memadai. Upaya peningkatan penyediaan pembiayaan dari sumber tersebut, antara lain, dilakukan dengan peningkatan kinerja pemungutan, penyempurnaan dan penambahan jenis retribusi, serta pemberian keleluasaan bagi Daerah untuk menggali sumber-sumber penerimaan khususnya dari sektor retribusi daerah melalui Undang-undang Nomor 18 Tahun 1997 tentang Pajak Daerah dan Retribusi Daerah sebagaimana telah diubah dengan Undang-undang Nomor 28 Tahun 2009.

Salah satu sumber Pendapatan Asli Daerah yaitu retribusi daerah. Retribusi Daerah selain sebagai salah satu sumber penerimaan bagi pemerintah daerah juga merupakan faktor yang dominan peranannya dan kontribusinya untuk menunjang pemerintah daerah. Retribusi Daerah, yang selanjutnya disebut Retribusi, adalah pungutan Daerah sebagai pembayaran atas jasa atau pemberian izin tertentu yang khusus disediakan dan/atau diberikan oleh Pemerintah Daerah untuk kepentingan orang pribadi atau badan.

Kabupaten Merangin merupakan salah satu Kabupaten yang melaksanakan otonomi daerah dan menjadikan retribusi daerah sebagai salah satu sumber pendapatan asli di daerahnya untuk memenuhi kebutuhan belanja pemerintahan dan pembangunan daerah. Dari beberapa sumber Pendapatan Asli Daerah (PAD), retribusi daerah merupakan salah satu sumber pendapatan asli daerah yang paling penting karena setiap tahunnya retribusi daerah mampu memberikan sumbangan yang cukup besar bagi penerimaan daerah khususnya Kabupaten Merangin. Sebagai gambaran selama periode 2009-2013 realisasi retribusi daerah mengalami fluktuatif. Pada tahun 2011 ditargetkan retribusi daerah sebesar Rp.13.340.743.120,00 terealisasi sebesar Rp. 12.164.534.792,00 atau 91,18\% dan pada tahun 2012 target retribusi daerah sebesar Rp. 332.000.000,00,- terealisasi sebesar Rp. 363.087.703,00 atau sebesar 109,36\% kemudian tahun 2013 terealisasi sebesar Rp. 17.072.974.042,00 atau 82,03\%. Secara keseluruhan rata- rata efektivitas retribusi daerah selama periode 2009 sampai dengan 2013 sebesar 87,03 persen setiap tahunnya.

Sedangkan kontribusi retribusi daerah terhadap Pendapatan Asli Daerah kabupaten Merangin pada selama tahun 2009-2013 mengalami fluktuatif. Pada tahun 2011 kontribusi retribusi daerah terhadap Pendapatan Asli Daerah (PAD) sebesar 34,36\%, dan tahun 2012 kontribusi retribusi daerah terhadap Pendapatan Asli Daerah (PAD) sebesar 1,55\%, kemudian kontribusi retribusi daerah terhadap Pendapatan Asli 
Daerah (PAD) meningkat sebesar 38,45\% pada tahun 2013. Secara keseluruhan selama tahun 2009 sampai 2013 rata-rata kontribusi retribusi daerah terhadap Pendapatan Asli Daerah (PAD) kabupaten Merangin adalah sebesar $25,08 \%$ setiap tahunnya. Berdasarkan latar belakang yang telah diuraikan tersebut, maka peneliti tertarik melakukan penelitian dengan judul: "Efektivitas Penerimaan Dan Kontribusi Retribusi Daerah Terhadap Pendapatan Asli Daerah Kabupaten Merangin “.

Berdasarkan beberapa uraian diatas, maka dibuat beberapa perumusan masalah adalah : berapa besar kontribusi retribusi daerah dan jenis retribusi daerah terhadap Pendapatan Asli Daerah di Kabupaten Merangin periode 2009-2013 ? dan berapa besar tingkat efektivitas retribusi daerah di Kabupaten Merangin periode 2009-2013 ?

\section{METODE PENELITIAN}

\section{Jenis dan Sumber Data}

Adapun jenis data yang digunakan dalam penelitian ini adalah data sekunder, data sekunder merupakan data penelitian yang diperoleh peneliti secara tidak langsung melalui media perantara (diperoleh dan dicatat oleh pihak lain). Adapun data sekundernya adalah laporan realisasi penerimaan Pendapatan Asli Daerah Kabupaten Merangin tahun 2009-2013 diperoleh dari Dinas Pengelolaan Keuangan dan Aset Daerah Kabupaten Merangin dan Badan Pusat Statistik Kabupaten Merangin.

\section{Metode Pengumpulan Data}

Metode pengumpulan data pada penelitian ini dilakukan dengan penelusuran data sekunder, data yang digunakan penelitian ini dikumpulkan dengan metode dokumentasi. Dokumentasi merupakan perolehan proses perolehan dokumen dengan mengumpulkan, mengcopy dokumen-dokumen yang ada dan mempelajari data-data yang diperlukan. Dalam penelitian ini data dokumentasi yang dimaksud untuk memperoleh gambaran tentang praktek pengungkapan laporan keuangan pemerintah daerah.

\section{Metode Analisis Data}

1. Untuk menjawab tujuan pertama dalam penelitian ini yaitu mengetahui besar kontribusi retribusi daerah dan jenis retribusi daerah terhadap Pendapatan Asli Daerah Kabupaten Merangin tahun 2009-2013. Pendekatan yang digunakan adalah pendekatan yang dikemukakan oleh Ritonga dalam Rizki Destiani Putri (2012) setelah disesuaikan dengan variabel yang diukur dalam penelitian ini, maka rumusnya menjadi :

a. Kontribusi retribusi daerah terhadap Pendapatan Asli Daerah

$K R D_{t}=\frac{R D_{t}}{P A D_{t}} \times 100 \%$

b. Kontribusi jenis retribusi daerah terhadap Pendapatan Asli Daerah

$K J R D_{t}=\frac{J R D_{t}}{P A D_{t}} \times 100 \%$

Dimana :

KRDt = Kontribusi Retribusi Daerah tahun

tertentu. $\mathrm{RDt}=$ Retribusi Daerah tahun tertentu. 
KJRDt $=$ Kontribusi jenis retribusi daerah tahun

tertentu. JRDt $=$ Jenis Retribusi Daerah tahun tertentu.

PADt $\quad=$ Realisasi Pendapatan Asli Daerah tahun tertentu.

Kriteria kontribusi menurut Tim Litbang Depdagri-Fisipol UGM 1991 yang dikutip Yulia Anggara Sari, (2010) dalam Rezki Destiani Putri (2012) adalah sebagai berikut :
a. $00,00 \%-10 \%=$ Sangat kurang
b. $10,10 \%-20 \%=$ kurang
c. $20,10 \%-30 \%=$ sedang
d. $30,10 \%-40 \%=$ cukup baik
e. $40,10 \%-50 \%=$ baik
f. Diatas $50 \%=$ sangat baik

2. Untuk menjawab tujuan kedua dalam penelitian ini yaitu mengetahui besar tingkat efektivitas Retribusi Daerah di Kabupaten Merangin tahun 2009- 2013. Pendekatan yang digunakan menurut Abdul Halim, (2001) setelah disesuaikan dengan variabel yang diukur dalam penelitian ini, maka rumusnya menjadi :

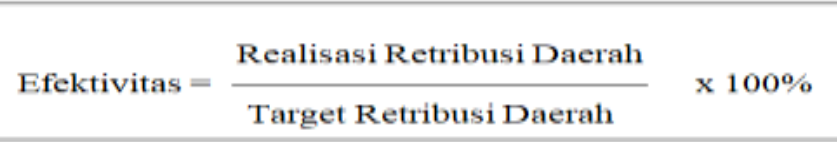

Nilai efektivitas diukur dengan kriteria penilaian kinerja anggaran menurut Bana, (2001) dalam Betta Sari Novalita adalah sebagai berikut:
a. Lebih dari $100 \%=$ sangat efektif
b. $90,01 \%-100 \%=$ efektif
c. $80,01 \%-90,00 \%$ = cukup efektif
d. $60,01 \%-80,00 \%=$ kurang efektif
Kurang dari $60 \%=$ tidak efektif

\section{HASIL DAN PEMBAHASAN}

\section{Kontribusi Retribusi Daerah Terhadap PAD Kabupaten Merangin}

Berdasarkan perhitungan tabel 1. Dapat dilihat kontribusi retribusi daerah terhadap Pendapatan Asli Daerah berfluktuatif pada setiap tahunnya dari 20092013.

Tabel 1

Kontribusi Retribusi Daerah Terhadap Pendapatan Asli Daerah (PAD) di Kabupaten Merangin Tahun 2009-2013

\begin{tabular}{|c|r|r|c|}
\hline Tahun & $\begin{array}{c}\text { Realisasi Retribusi } \\
\text { Daerah (Rp) }\end{array}$ & $\begin{array}{c}\text { Realisasi PAD } \\
(\mathbf{R p})\end{array}$ & $\begin{array}{c}\text { Kontribusi } \\
(\mathbf{\%})\end{array}$ \\
\hline 2009 & $6.879 .750 .024,00$ & $32.710 .601 .617,49$ & 21,03 \\
\hline 2010 & $7.827 .313 .607,00$ & $26.078 .135 .516,48$ & 30,01 \\
\hline 2011 & $12.164 .534 .792,00$ & $35.400 .815 .857,46$ & 34,36 \\
\hline 2012 & $363.087 .703,00$ & $23.348 .709 .483,57$ & 1,55 \\
\hline 2013 & $17.072 .974 .042,00$ & $44.396 .136 .300,39$ & 38,45 \\
\hline \multicolumn{3}{r|}{ Rata-rata } & $\mathbf{2 5 , 0 8}$ \\
\hline
\end{tabular}

Sumber: DPKAD Kabupaten Merangin (data diolah) 
Rata-rata kontribusi retribusi daerah terhadap Pendapatan Asli Daerah Kabupaten Merangin taun 2009-2013 adalah sebesar 25,08\%. persentase kontribusi tertinggi terdapat pada tahun 2013 dengan persentase kontribusi sebesar 38,45\% tingginya kontribusi ini tidak terlepas dari meningkatnya penerimaan retribusi daerah yang mengakibatkan perannya dalam struktur penerimaan Pendapatan Asli Daerah (PAD) Kabupaten Merangin mengalami peningkatan pula. Kemudian persentase terendah terdapat pada tahun 2012 dengan persentase kontribusi sebesar 1,55\% rendahnya kontribusi pada tahun ini dikarenakan pemerintah hanya memungut beberapa retribusi daerah saja sehingga hanya sedikit retribusi daerah yang memberikan kontribusinya. Secara grafis Perkembangan kontribusi retribusi daerah dapat dilihat pada gambar berikut ini.

\section{Gambar 1}

Kontribusi Penerimaan Retribusi Daerah Terhadap Pendapatan Asli Daerah

(PAD) Kabupaten Merangin Tahun 2009-2013

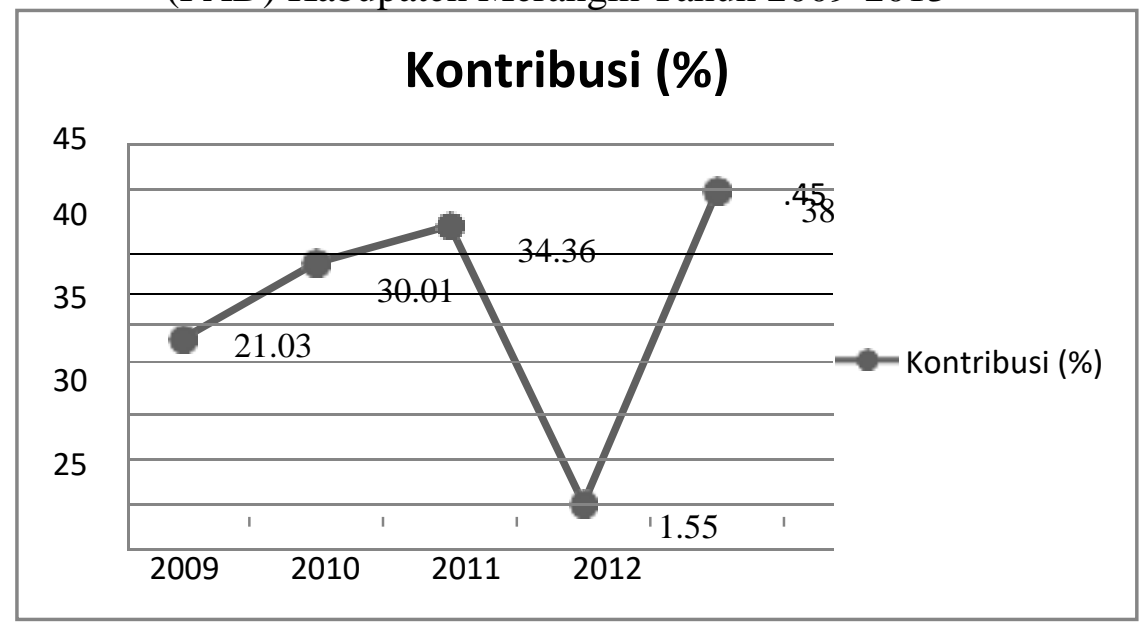

\section{Kontribusi Retribusi Jasa Umum Terhadap PAD Kabupaten Merangin.}

Berdasarkan perhitungan tabel 2. Dapat dilihat kontribusi retribusi jasa umum terhadap Pendapatan Asli Daerah berfluktuatif pada setiap tahunnya dari 2009- 2013.

Tabel 2

Kontribusi Retribusi Jasa Umum Terhadap Pendapatan Asli Daerah (PAD) di Kabupaten Merangin Tahun 2009-2013

\begin{tabular}{|c|r|c|c|}
\hline Tahun & $\begin{array}{c}\text { Realisasi Retribusi } \\
\text { Jasa Umum (Rp) }\end{array}$ & $\begin{array}{c}\text { Realisasi PAD } \\
(\mathbf{R p})\end{array}$ & $\begin{array}{c}\text { Kontribusi } \\
(\mathbf{\%})\end{array}$ \\
\hline 2009 & $4.943 .237 .870,00$ & $32.710 .601 .617,49$ & 15,11 \\
\hline 2010 & $5.362 .714 .519,00$ & $26.078 .135 .516,48$ & 20,56 \\
\hline 2011 & $8.694 .961 .085,00$ & $35.400 .815 .857,46$ & 24,56 \\
\hline 2012 & $215.387 .000,00$ & $23.348 .709 .483,57$ & 0,92 \\
\hline 2013 & $15.558 .410 .781,00$ & $44.396 .136 .300,39$ & 35,04 \\
\hline \multicolumn{3}{|c|}{ Rata-rata } & $\mathbf{1 9 , 2 4}$ \\
\hline
\end{tabular}

Sumber: DPKAD Kabupaten Merangin (data diolah) 
Secara rata-rata selama tahun 2009-2013 kontribusi retribusi daerah jenis jasa umum terhadap penerimaan Pendapatan Asli Daerah (PAD) Kabupaten Merangin sebesar 19,24\% setiap tahunnya dan masih berkategori kurang berkontribusi. Persentase kontribusi tertinggi terdapat pada tahun 2013 dengan persentase kontribusi sebesar 35,04\% disebabkan adanya upaya pemerintah kabupaten Merangin dalam penambahan sub-sub retribusi jasa umum sehingga peningkatan penerimaan realisasi retribusi jasa umum dan peningkatan Pendapatan Asli Daerah (PAD), kemudian persentase terendah terdapat pada tahun 2012 dengan persentase kontribusi sebesar $0,92 \%$. Secara grafis perkembangan retribusi daerah jenis jasa umum terhadap pendapatan Asli Daerah (PAD) Kabupaten Merangin dapat dilihat pada gambar 2. berikut ini :

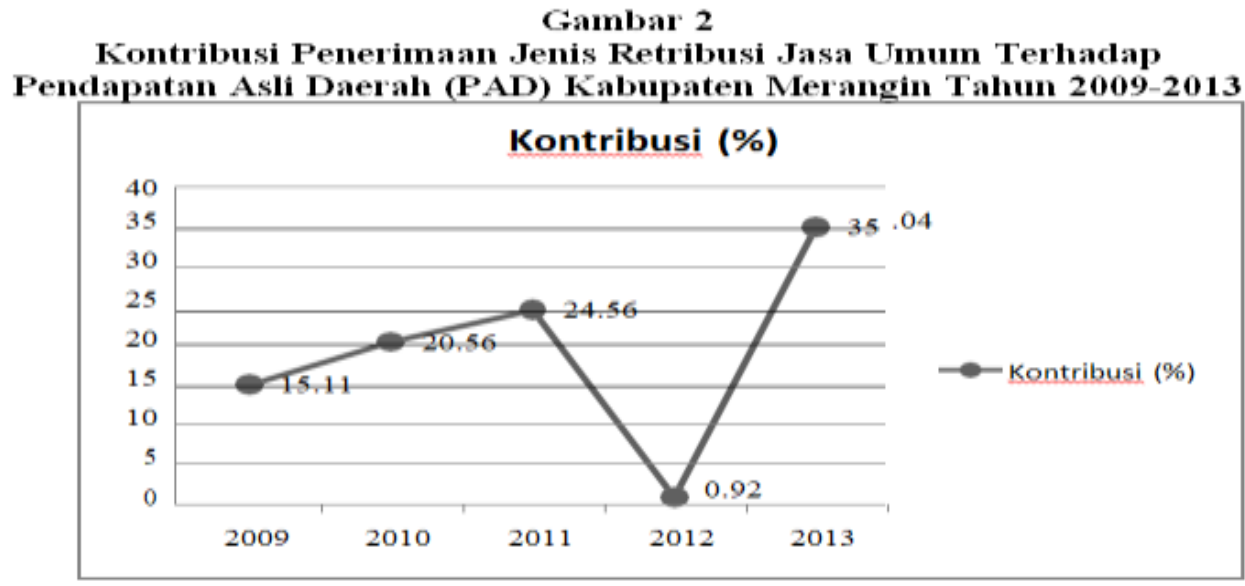

\section{Kontribusi Retribusi Jasa Usaha Terhadap PAD Kabupaten Merangin}

Berdasarkan perhitungan tabel 3. Dapat dilihat kontribusi retribusi jasa usaha terhadap Pendapatan Asli Daerah Kabupaten Merangin berfluktuatif pada setiap tahunnya dari 2009-2013.

Tabel 3

Kontribusi Retribusi Jasa Usaha Terhadap Pendapatan Asli Daerah (PAD) di Kabupaten Merangin Tahun 2009-2013

\begin{tabular}{|c|r|c|c|}
\hline Tahun & $\begin{array}{c}\text { Realisasi Retribusi } \\
\text { Jasa Usaha (Rp) }\end{array}$ & $\begin{array}{c}\text { Realisasi PAD } \\
(\mathbf{R p})\end{array}$ & $\begin{array}{c}\text { Kontribusi } \\
(\boldsymbol{\%})\end{array}$ \\
\hline 2009 & $1.357 .321 .358,00$ & $32.710 .601 .617,49$ & 4,15 \\
\hline 2010 & $1.662 .550 .193,00$ & $26.078 .135 .516,48$ & 6,37 \\
\hline 2011 & $2.413 .023 .668,00$ & $35.400 .815 .857,46$ & 6,82 \\
\hline 2012 & $129.895 .000,00$ & $23.348 .709 .483,57$ & 0,56 \\
\hline 2013 & $1.384 .680 .580,00$ & $44.396 .136 .300,39$ & 3,12 \\
\hline \multicolumn{4}{|c|}{ Rata-rata } \\
\hline
\end{tabular}

Sumber : DPKAD Kabupaten Merangin (data diolah)

Secara rata-rata selama tahun 2009-2013 kontribusi retribusi daerah jenis jasa usaha terhadap penerimaan Pendapatan Asli Daerah (PAD) Kabupaten Merangin sebesar 4,20\% setiap tahunnya dan masih berkategori sangat kurang berkontribusi. 
Persentase kontribusi tertinggi terdapat pada tahun 2011 dengan persentase kontribusi sebesar $6,82 \%$ meningkatnya kontribusi pada tahun ini disebabkan karena meningkatnya penerimaan jenis retribusi jasa usaha seperti retribusi pemakaian daerah, retribusi tempat khusus parkir, retribusi terminal, retribusi penyedotan kakus, dan retribusi rekreasi dan olah raga, kemudian persentase terendah terdapat pada tahun 2012 dengan persentase kontribusi sebesar 0,56\%. Secara grafis perkembangan retribusi jasa usaha terhadap Pendapatan Asli Daerah (PAD) Kabupaten Merangin dapat dilihat pada gambar 3 berikut ini :

Gambar 3.

Kontribusi Penerimaan Jenis Retribusi Jasa Usaha Terhadap Pendapatan Asli Daerah (PAD) di Kabupaten Merangin Tahun 2009-2013

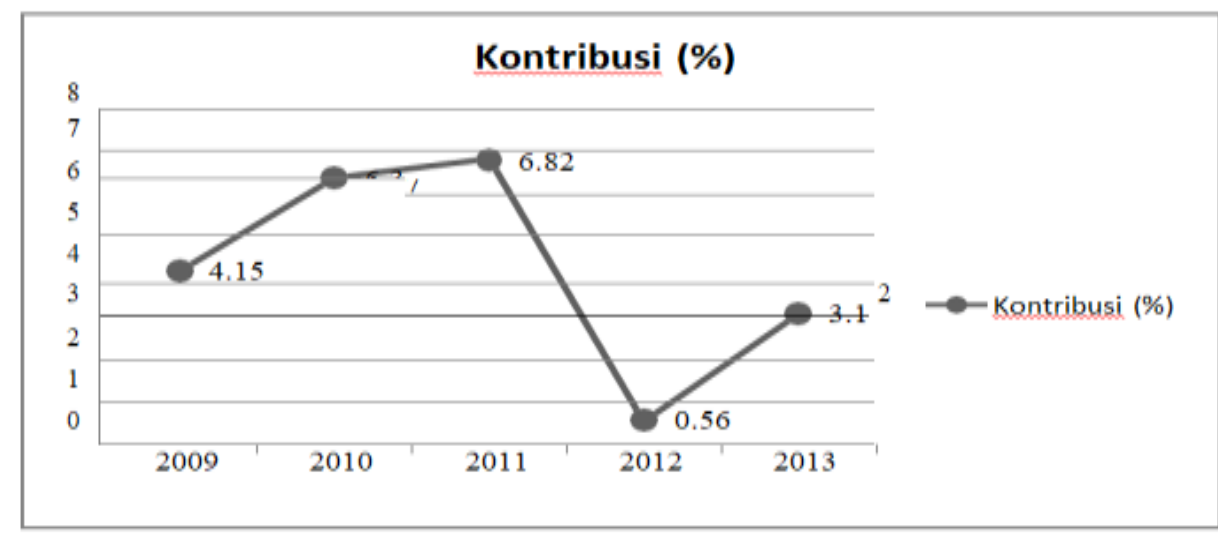

\section{Kontribusi Jenis Retribusi Perizinan Tertentu Terhadap PAD Kabupaten Merangin}

Berdasarkan perhitungan tabel 4. Dapat dilihat kontribusi retribusi perizinan tertentu terhadap Pendapatan Asli Daerah berfluktuatif pada setiap tahunnya dari 20092013.

Tabel 4

Kontribusi Retribusi Perizinan Tertentu Terhadap Pendapatan Asli Daerah (PAD) di Kabupaten Merangin Tahun 2009-2013

\begin{tabular}{|c|r|r|c|}
\hline Tahun & $\begin{array}{c}\text { Realisasi Retribusi } \\
\text { Perizinan Tertentu (Rp) }\end{array}$ & Realisasi PAD (Rp) & $\begin{array}{c}\text { Kontribusi } \\
(\mathbf{\%})\end{array}$ \\
\hline 2009 & $579.190 .796,00$ & $32.710 .601 .617,49$ & 1,77 \\
\hline 2010 & $842.048 .895,00$ & $26.078 .135 .516,48$ & 3,23 \\
\hline 2011 & $1.057 .950 .039,00$ & $35.400 .815 .857,46$ & 2,99 \\
\hline 2012 & $202.800,00$ & $23.348 .709 .483,57$ & 0,09 \\
\hline 2013 & $129.882 .681,00$ & $44.396 .136 .300,39$ & 0,29 \\
\hline \multicolumn{4}{|c|}{ Rata-rata } \\
\hline
\end{tabular}

Sumber : DPKAD Kabupaten Merangin (data diolah)

Secara rata-rata selama tahun 2009-2013 kontribusi retribusi daerah jenis jasa usaha terhadap penerimaan Pendapatan Asli Daerah (PAD) Kabupaten Merangin sebesar 1,67 persen setiap tahunnya dan masih berkategori sangat kurang berkontribusi. Persentase kontribusi tertinggi terdapat pada tahun 2010 sebesar 3,23\% hal ini dikarenakan jenis retribusi perizinan tertentu penerimaannya meningkat dari tahun 
sebelumnya, kemudian persentase terendah terdapat pada tahun 2012 dengan persentase kontribusi sebesar $0,09 \%$. Secara grafis perkembangan jenis retribusi perizinan tertentu terhadap Pendapatan Asli Daerah Kabupaten Merangin dapat dilihat pada gambar 4 berikut ini:

Gambar 4

Kontribusi Penerimaan Jenis Retribusi Perizinan Tertentu Terhadap Pendapatan Asli Daerah di Kabupaten Merangin

Tahun 2009-2013

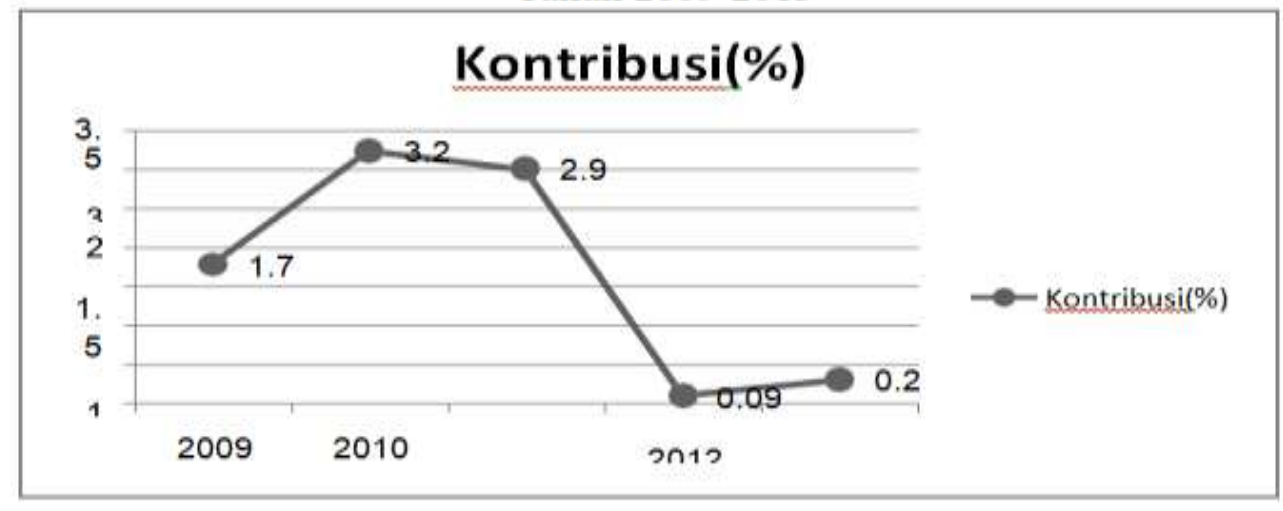

\section{Efektivitas Retribusi Daerah Kabupaten Merangin}

Selama tahun 2009-2013 rata-rata efektivitas retribusi daerah Kabupaten Merangin cukup efektif. Untuk lebih jelasnya dapat dilihat pada tabel 5 berikut ini :

Tabel 5

Efektivitas Retribusi Daerah Kab. Merangin Tahun 2009-2013

\begin{tabular}{|c|c|c|c|c|}
\hline $\begin{array}{c}\text { Tahun } \\
\text { Anggaran }\end{array}$ & $\begin{array}{l}\text { Target Retribusi } \\
\text { Daerah (Rp) }\end{array}$ & $\begin{array}{l}\text { Realisasi Retribusi } \\
\text { Daerah (Rp) }\end{array}$ & $\begin{array}{c}\text { Efektivitas } \\
(\%)\end{array}$ & $\begin{array}{c}\text { Kriteria } \\
\text { Efektivitas }\end{array}$ \\
\hline 2009 & $9.443 .177 .000,00$ & $6.879 .750 .024,00$ & 72,85 & Kurang Efektif \\
\hline 2010 & $9.816 .774 .000,00$ & 7.827.313.607,00 & 79,73 & Kurang Efektif \\
\hline 2011 & $13.340 .743 .120,00$ & $12.164 .534 .792,00$ & 91,18 & Efektif \\
\hline 2012 & $332.000 .000,00$ & $363.087 .703,00$ & 109,36 & Sangat Efektif \\
\hline 2013 & $20.812 .809 .529,60$ & $17.072 .974 .042,00$ & 82,03 & Cukup Efektif \\
\hline \multicolumn{3}{|c|}{ Rata-rata } & 87,03 & Cukup Efektif \\
\hline
\end{tabular}

Sumber: DPKAD Kabupaten Merangin (data diolah)

Secara rata-rata selama tahun 2009-2013 efektivitas retribusi daerah di Kabupaten Merangin adalah sebesar $87,03 \%$ dan ini dikatakan cukup efektif. Persentase efektivitas tertinggi terjadi pada tahun 2012 sebesar 109,36\% dan dikatakan sangat efektif meskipun penerimaan realisasinya paling rendah dibanding tahun sebelumnya dikarenakan hanya ada dua retribusi yang dipungut tetapi nilai efektivitasnya meningkat. Kemudian persentase efektivitas terendah terjadi pada tahun 2009 yaitu sebesar 72,85\%. Secara grafis perkembangan efektivitas retribusi daerah Kabupaten Merangin dapat dilihat pada gambar 5 berikut ini : 
Gambar 5

Efektivitas Retribusi Daerah Kabupaten Merangin Tahun 2009-

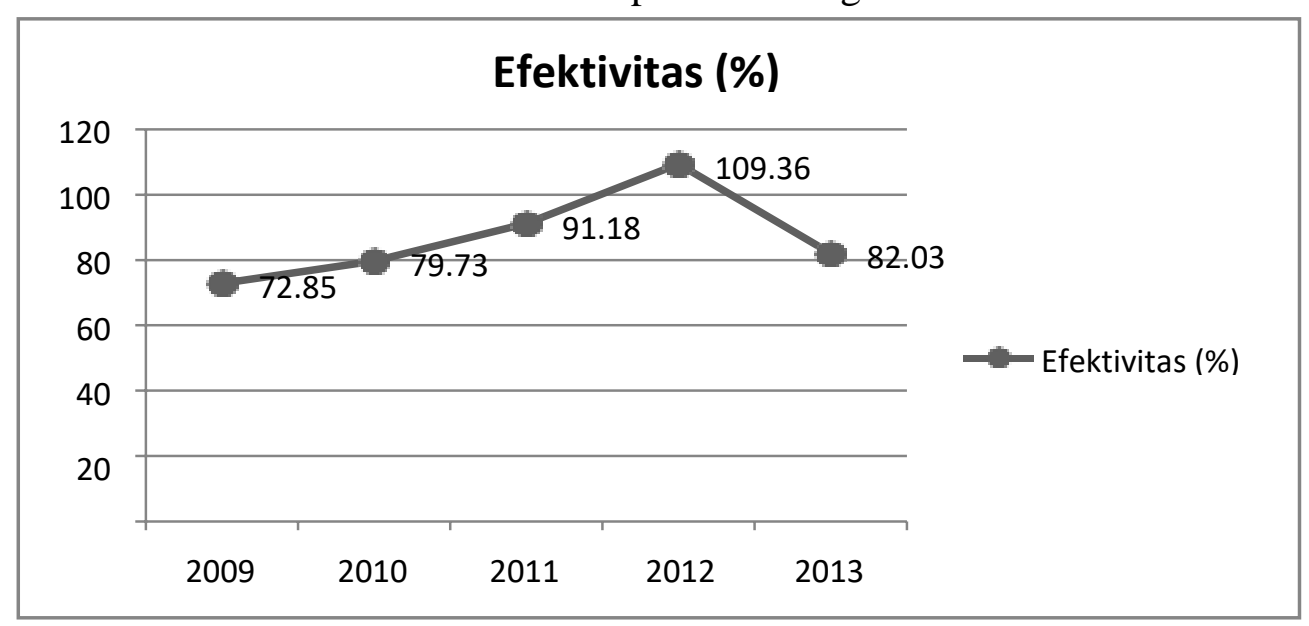

2013

\section{SIMPULAN DAN SARAN}

Selama kurun waktu 2009-2013 kontribusi retribusi daerah terhadap Pendapatan Asli Daerah (PAD) Kabupaten Merangin secara rata-rata adalah sebesar 25,08\% pertahun. Kontribusi jenis retribusi daerah yang terbesar dalam Pendapatan Asli Daerah (PAD) Kabupaten Merangin adalah retribusi jasa umum rata-rata sebesar 19,24\%, kemudian kontribusi retribusi jasa usaha rata-rata sebesar 4,20\% dan kontribusi terendah yaitu pada retribusi perizinan tertentu dengan rata-rata sebesar 1,67\% pertahunnya.

Secara rata-rata efektivitas penerimaan retribusi daerah di Kabupaten Merangin selama tahun 2009-2013 adalah sebesar 82,34\% pertahun, dari hasil efektivitas ini menunjukkan bahwa Kabupaten Merangin sudah cukup efektif dalam pemungutan retribusi daerahnya.

\section{DAFTAR PUSTAKA}

Amri Siregar (2009). Analisis Tingkat Efektivitas Pajak dan Retribusi Daerah Sebagai Pendapatan Asli Daerah (PAD) Sumatera Utara. Skripsi. Universitas Sumatera Utara. Medan. Dipublikasikan.

Adelina, Rima (2011). Analisis Efektifitas dan Kontribusi Penerimaan Pajak Bumi dan Bangunan (PBB) terhadap Pendapatan Daerah di Kabupaten Gresik.Jurnal Akuntansi Vol.III No.2. Universitas Negeri Surabaya. Surabaya.

BPS, 2013. Merangin Dalam Angka. Kabupaten Merangin

Betta Sari Novalita. Peranan Pajak Daerah Dalam Meningkatkan Pendapatan Asli Daerah Kabupaten Bogor. Universitas Gunadarma

Darise, Nurlan (2009). Pengelolaan Keuangan Pada Satuan Kerja Perangkat Daerah (SKPD) Dan BLU. Edisi kedua . Jakarta: PT. Indeks.

Depdagri, Permendagri Nomor 21 Tahun 2011 Tentang Pedoman Pengelolaan Keuangan Daerah di akses melalui www.depdagri.go.id pada tanggal 25 Januari 2015.

Dinas Pengelolaan Keuangan dan Aset Daerah Kabupaten Merangin. 2013. Realisasi Penerimaan Pendapatan Asli Daerah Kabupaten Merangin 2009-2013. Kabupaten Merangin. 
Elvi Rahmi (2013). Analisis Kontribusi Penerimaan Retribusi Izin Mendirikan Bangunan Terhadap Pendapatan Asli Daerah (PAD) Kabupaten Bungo Tahun 2007-2011. Skripsi. Tidak Dipublikasikan. FE Unja.

Gozzali Ar Rozzaq (2010). Kontribusi dan Efektifitas Retribusi Jasa Umum Terhadap Penerimaan Pendapatan Asli Daerah. Skripsi. Universitas Sebelas Maret. Dipublikasikan

Halim Abdul (2008). Akuntansi Sektor Publik: Akuntansi Keuangan Daerah.Jakarta: Salemba Empat.

Kaho, Josef Riwu (2007). Prospek Otonomi daerah di negara Republik Indonesia. Jakarta: PT RajaGrafindo Persada.

Peraturan Pemerintah Nomor 58 Tahun 2005 tentang Pengelolaan Keuangan Daerah diakses melalui http://www.itjen.depkes.go.id/pemerintah pada tanggal 25 Januari 2015

Peraturan Pemerintah No 66 Tahun 2001 Tentang Retribusi Daerah diakses melalui http://www.kemendagri.go.id/media/document pada tanggal 25 Januari 2015 , 2011. Undang-undang Otonomi Daerah. Bandung: Fokus Media

Rahayu, siti kurnia (2010). Perpajakan Indonesia Konsep dan Aspek Formal. Yogyakarta: Graha Ilmu.

Rizki Destiani Putri (2012). Analisis Penerimaan Retribusi Terminal Kabupaten Sarolangun Tahun 2004-2010. Skripsi. Tidak Dipublikasikan. FE Unja

Siahaan, Marihot P. (2013). Pajak daerah dan Retribusi Daerah. Edisi Revisi.Cetakan 3. Jakarta: Rajawali Pers.

Supardi (2008). Kontribusi Pendapatan Retribusi Daerah Terhadap Pendapatan Asli Daerah (PAD) di Kabupaten Bantul (Periode 1996/1997-2005). AKMENIKA UPY, Volume 2.

Undang-undang Nomor 23 Tahun 2014 Tentang Pemerintahan Daerah diakses melalui http://www.hukumonline.com/pusatdata/ pada tanggal 30 April 2015

Undang-undang Nomor 28 Tahun 2009 tentang Pajak Daerah dan Retribusi Daerah, diakses melalui http://keuda.kemendagri.go.id/produkhukum/ pada tanggal 25 Januari 2015

Undang-undang Nomor 33 Tahun 2004 Tentang Perimbangan Keuangan antara Pemerintah Pusat dan Daerah diakses melalui http://www.itjen.depkes.go.id/ pada tanggal 25 Januari 2015

Widjaja, H.A.W. (2011). Otonomi daerah dan Daerah Otonom. Edisi 6. Jakarta: Rajawali Pers.

Yani, Ahmad (2013). Hubungan Keuangan antara Pemerintah Pusat dan

Daerah di Indonesia. Edisi Revisi. Jakarta: Rajawali Pers. 